\title{
EVALUATION OF ANTI-INFLAMMATORY AND HEALING ACTIVITY OF A NANO-STRUCTURED LIPID CARRIER CONTAINING TUCUMAN BUTTER OIL AND BUTTER ${ }^{1}$
}

\author{
AVALIAÇÃO DA ATIVIDADE ANTI-INFLAMATÓRIA E \\ CICATRIZANTE DE UM CARREADOR LIPÍDICO NANOESTRUTURADO \\ CONTENDO ÓLEO E MANTEIGA DE TUCUMÃ
}

\author{
Aline Rossato $^{2}$, Larissa da Silva Silveira ${ }^{2}$, Pâmella Schramm Oliveira ${ }^{2}$, \\ Walter Paixão de Souza Filho², Roger Wagner ${ }^{3}$, Bruna Klein ${ }^{3}$, Diego de Souza², \\ Matheus Dellaméa Baldissera ${ }^{4}$ e Michele Rorato Sagrillo ${ }^{5}$
}

\begin{abstract}
The Amazon region has a wide variety of native palm trees that have fruits and oilseeds. Among these palm trees, Pará tucumã (Astrocaryum vulgare) stands out, which provides the tucumã fruit from which its oil is extracted, which has anti-inflammatory, antioxidant, healing and antibacterial properties, among others. However, oils, like that of tucumã, are sensitive to thermal degradation, as well as oxidative reactions, which can reduce their pharmacological effectiveness. In this way, nanotechnology can be a tool to preserve the pharmacological properties of essential oils and increase their therapeutic effectiveness. Therefore, this study aims to develop a nanostructured lipid carrier (NLC) containing tucumã butter and oil, to analyze its in vitro properties of anti-inflammatory and healing activity. For that, tests of antiinflammatory activity and healing activity were performed by the Scratch test in vitro. The results of the tests demonstrated that the majority of the NLC concentrations showed anti and pro-inflammatory and healing activity.
\end{abstract}

Keywords: Tucumã; Anti-inflammatory activity; Healing; Nanoparticles.

\section{RESUMO}

A região Amazônica conta com uma ampla diversidade de palmeiras nativas que possuem frutos e sementes oleaginosas. Dentre essas palmeiras, destaca-se o tucumã do Pará (Astrocaryum vulgare), que fornece o fruto tucumã de onde é extraído seu óleo que possui propriedades anti-inflamatórias, antioxidantes, cicatrizantes, antibacterianas, entre outros. No entanto, os óleos, assim como o de tucumã são sensíveis a degradações térmicas, bem como por reações oxidativas, o que pode reduzir sua eficácia farmacológica. Desta forma, a nanotecnologia pode ser uma ferramenta para preservar as propriedades farmacológicas dos óleos essenciais e aumentar sua eficácia terapêutica. Sendo assim, este estudo tem por objetivo desenvolver um carreador lipídico nanoestruturado (CLN) contendo óleo e manteiga de tucumã, analisar suas propriedades in vitro de atividade anti-inflamatória e cicatrizante. Para isso foram realizados testes de atividade anti-inflamatória e atividade cicatrizante pelo ensaio de Scratch in vitro. Os resultados dos

${ }^{1}$ Trabalho de Mestrado em Nanociências- Universidade Franciscana, Santa Maria - RS.

${ }^{2}$ Programa de Pós-Graduação em Nanociências- Universidade Franciscana, Santa Maria - RS. larissasilveirars@outlook.com; schramm.pso@gmail.com; walter_paixao@hotmail.com; diegodesouza81@gmail.com

${ }^{3}$ Laboratório de Bromatologia - Universidade Federal de Santa Maria - RS. rogerwag@gmail.com; brunaklein06@yahoo.com.br

${ }^{4}$ Programa de Pós-graduação em Farmacologia - Universidade Federal de Santa Maria - RS. matheusd.biomed@yahoo.com.br

${ }^{5}$ Orientadora. Professora Adjunta do PPG Nanociências - UFN. sagrillorm18@gmail.com 
ensaios demonstraram que a maioria das concentrações do CLN apresentaram atividade anti e próinflamatórias e cicatrizante.

Palavras-chave: Tucumã; Atividade anti-inflamatória; Cicatrização; Nanopartículas.

\section{INTRODUCTION}

Bioactives from fruits and vegetables are receiving great attention due to their low cost and wide margin of safety in addition to therapeutic efficacy (SOUZA FILHO et al., 2012). The use of herbal medicines in anti-inflammatory processes and in the healing of skin lesions has been widely analyzed in experimental studies. With scientific progress, involving chemical and pharmacological studies of medicinal plants, new bioactive agents with therapeutic properties were obtained (MACEDO et al., 2017).

In this context, tucumã is found, whose fruits are used for food and is considered a rich source of bioactive, has a high content of lipids, a large amount of carotene, a precursor to vitamin A, high levels of fiber and vitamin E. The oil is edible and yellow in color, can be extracted from the fruit's mesocarp, has high-value organoleptic and nutritious characteristics for the food, cosmetic and pharmaceutical industry, with antioxidant, anti-inflammatory and antibacterial activities, among others (FERREIRA et al., 2008).

There are countless factors that hinder the effectiveness of vegetable oils, as they can undergo oxidation, and consequent loss of pharmacological properties. Thus, in order to reduce or prevent the loss of pharmacological activity of a substance, there was a need to develop mechanisms to increase the efficiency of formulations. In this context, nanotechnology has been considered an important alternative in reducing or preventing loss of pharmacological activity (FERNANDES, 2010). Among the alternatives, NLC can be used in various formulations, thanks to its physical, aesthetic and sensorial structure, being excellent means of carrying substances, promoting an increase in bioavailability, solubility and protection of the physical-chemical properties of the asset (ATTAMA et al., 2012).

Considering the current demand in the use of natural raw materials and the call for the valorization of Brazilian biodiversity, tucumã oil, rich in bioactive substances favorable to the development of new products, appears as an alternative, but its chemical matrix has oxidative degradable and photodegradable compounds, in addition to presenting low solubility in water. In this way, the association with nanotechnology can not only preserve the bioactives of tucumã oil, but also enhance and improve its pharmacological effects, in addition to providing a controlled and gradual release of the assets. 


\section{MATERIALS AND METHOD}

\section{PURCHASE OIL AND TUCUMAN BUTTER}

Tucumã oil and butter were purchased commercially from Indústria AmazonOil - (Pará, Brazil).

\section{PREPARATION AND CHARACTERIZATION OF NLC}

The NLC containing the tucumã oil and butter was prepared using a method developed by preformulation tests using Ultra Turrax ${ }^{\circledR}$ equipment and characterized according to $\mathrm{pH}$, polydispersity index (PDI), size and zeta potential. The diameter and PDI determinations of the nanoparticles were performed through dynamic light scattering; the zeta potential was measured by electrophoresis (Zetasizer® nano-Zs model ZEN 3600, Malvern), the determination of the $\mathrm{pH}$ of the nanoparticles was carried out in $\mathrm{pH}$-meter. In this study, the formulation was prepared at $\mathrm{n}=3$ and kept under different temperature and storage conditions (refrigerator at $28^{\circ} \mathrm{C}$, oven at $40^{\circ} \mathrm{C}$, room temperature with exposure to light and room temperature in a dark place) during the period of 60 days .

\section{EVALUATION OF ANTI-INFLAMMATORY NLC ACTIVITY WITH PHYTOHEMAGLUTININ}

PBMCs $(2 \times 105$ cells / mL) were plated in a 96-well plate (Corning Inc., NY, USA) with 50 $\mu \mathrm{L}$ of Phytohemagglutinin, kept in an oven at $37^{\circ} \mathrm{C}$ with $5 \% \mathrm{CO} 2$ for $48 \mathrm{~h}$. After this time, the cells were washed with phosphate buffered saline (PBS 1X, Gibco®), and treated with different concentrations of NLC for another $24 \mathrm{~h}$. After $24 \mathrm{~h}$ the plate was centrifuged and the supernatant removed to perform the MTT and ON tests. As a negative control, a culture of cells that were not treated and not stimulated with phytohemagglutinin was used, and as a positive control, cells that were not treated and stimulated with hydrogen peroxide (MACZYNSKI et al., 2016).

\section{SCRATCH IN VITRO TEST}

For the realization of the healing study, HFF-1 (human fibroblasts) were used. Before plating the cells, a central marking was performed using a permanent marker aiming at a better standardization in the making of the "cut" and measurements. This marking establishes a visual field in the well, which was analyzed after the establishment of the "cut" in the monolayer. After adhesion to the 96-well plate of fibroblast cell lines, with the aid of a syringe needle, a continuous streak was carried out on the medial surface of each well, and the volume of $20 \mu \mathrm{L}$ containing different concentrations 
of the NLC was added. This procedure causes a break in contact between the cells and their removal from a specific region of the plate, resulting in the formation of a mechanical lesion in the monolayer. The wells were washed with PBS (Gibco $\left.{ }^{\circledR}\right)$, composed of sodium chloride and sodium phosphate, to remove the debrided cells. The proliferation of adjacent cells towards free space on the plate was monitored at zero time, 24 and 48 hours through photographs.

To perform the analysis of images referring to the healing process of the various types of treatments, a script was developed in the Python programming language. Initially, the conductor of the experiment generated an image, 50x50 pixels in size, which represented a sample of cells, that is, of a fully healed region. From this image, the average and standard deviation of the color of its pixels in RGB format (Red - Red, Green - Green, and Blue - Blue) were calculated, whose values for each color vary from 0 to 255 . A From the calculated average, the analysis of the healing process of the images was started, analyzing them pixel by pixel. The color of a pixel is considered to be a cell if its RGB value is greater than or equal to the average minus the standard deviation, or less than or equal to the average plus the standard deviation. Otherwise, the pixel is considered non-cell. Thus, how many pixels, for each image, are within the cell and non-cell range, as well as the percentages of cell and non-cell in relation to the total number of pixels. Finally, the script generated a file, in table format, which was imported into the Excel software with the data obtained from the analysis of each sample.

\section{STATISTICAL ANALYSIS}

The analyzes were performed using one-way bilateral analysis of variance (ANOVA) followed by Dunnett's post hoc test. Values with $\mathrm{p}<0.05$ were considered statistically significant. The data were expressed as mean \pm standard deviation. The graphs were prepared using GraphPadPrism version 5.01 (GraphPad Software, La Jolla, CA, USA).

\section{RESULTS AND DISCUSSIONS}

\section{PREPARATION AND CHARACTERIZATION OF NLC}

The prepared formulation had a monodispersed distribution of particles showing a PDI value of $0.256 \pm 2$, an average size of $170.7 \pm 3 \mathrm{~nm}$, a zeta potential of $-18.2 \pm 2$ and a $\mathrm{pH}$ of $5.22-5.35$. When evaluating the NLC formulations under different conditions of temperature and storage, it can be observed that there were no significant changes in the stability of the formulations during the period of 60 days, in any of the conditions of storage and temperature that they were exposed to. 
The formulations stored in the refrigerator at $-4{ }^{\circ} \mathrm{C}$, showed a PDI value of $0.252 \pm 2$, an average size of $168.9 \pm 3 \mathrm{~nm}$, a potential zetade of $-18.8 \pm 2$ and a $\mathrm{pH}$ of $5.32-5.55$. The formulations stored in an oven at $40{ }^{\circ} \mathrm{C}$ showed a PDI value of $0.255 \pm 2$, an average size of $165.9 \pm 3 \mathrm{~nm}$, a zetal potential of $-18.6 \pm 2$ and a $\mathrm{pH}$ of $5.42-5.53$. When stored at room temperature, in a dark environment, the formulations showed a PDI value of $0.257 \pm 2$, an average size of $171.3 \pm 3 \mathrm{~nm}$, zetade potential $-18.4 \pm 2$ and a $\mathrm{pH}$ of $5.37-5.43$ and in a clear environment, PDI values of $0.254 \pm 2$, average size of $171.8 \pm 3 \mathrm{~nm}$, zetade potential $-18.0 \pm 2$ and $\mathrm{pH}$ of $5.39-5.45$.

A complete characterization of NLC is important, considering the influence of such parameters in terms of biological effects, because the physical-chemical analysis provides important information about the stability of these types of nanoformulation over time (GIORDANI et al., 2014). Particle size is an important attribute of lipid nanocarriers, which affects stability, encapsulation efficiency, drug release profile, biodistribution, mucus adhesion and cell uptake. A rapid increase in particle size, for example, indicates low stability of the colloidal system (BAHARI and HAMISHEHK, 2016).

For a particle to be considered nanometric, it is necessary that at least one of its dimensions is less than $1000 \mathrm{~nm}$ and that this changes its nature properties. Thus, the results found for the sizes of the produced nanoparticles agree with the criteria established in the literature, which can contribute to an adequate stability and improvement in therapeutic efficacy. The results of the characterization of the nanoparticles indicate adequate homogeneity, all formulations must be monodispersed (PDI $<0.3$ ) and diameter less than $300 \mathrm{~nm}$.

The numerical value of the PDI ranges from 0.0 (for a sample perfectly uniform in relation to the particle size) to 1.0 (for a highly polydispersed sample with several populations of particle sizes). Values of 0.2 and below are generally considered acceptable in practice for nanoparticles based on material polymers. In drug delivery applications using lipid-based carriers, such as liposomes and nanoliposomes formulations, a PDI of 0.3 and below is considered acceptable and indicates a homogeneous population of phospholipid vesicles (CHEN et al., 2014). In this study, the polydispersity index was low $(<0.3)$ for all dispersions obtained, indicating the formation of monodispersed systems. The NLC stability studies showed that it remained stable for a period of 60 days under all established temperature and storage conditions. There were no visible trends in sedimentation, phase separation or aggregation over time.

Considering that the zeta potential reflects the electrostatic repulsion between the particles, and that the standard value of the zeta potential is equal to or greater than $+/-30 \mathrm{mV}$, it is associated with stable solutions, it can be said that the prepared formulation was stable. The characterization and stability results obtained demonstrate that the NLC was successfully developed, remaining stable for 60 days, in all temperature and storage conditions to which it was exposed. 
ANTI-INFLAMMATORY ACTIVITY OF THE NLC EXPOSED TO

PHYTOHEMAGLUTININ

Studies of the anti-inflammatory activity of NLC containing tucumã oil and butter have been developed. The results of anti-inflammatory activity with Phytohemagglutinin demonstrated that the CLN showed anti-inflammatory activity in the concentrations of $3125,1562.5$ and $781.25 \mu \mathrm{g} / \mathrm{mL}$ mediated by the significant decrease in the production of NO, (figure 1).

Figure 1 - Results of anti-inflammatory activity with Nanostructured Lipid Carrier Phytohemagglutinin in different concentrations. The data are presented as $\%$ of the untreated control group (NC). Values with $\mathrm{p}<0.05$ were considered statistically significant.*results in relation to the CN. \# results compared to PHA control.
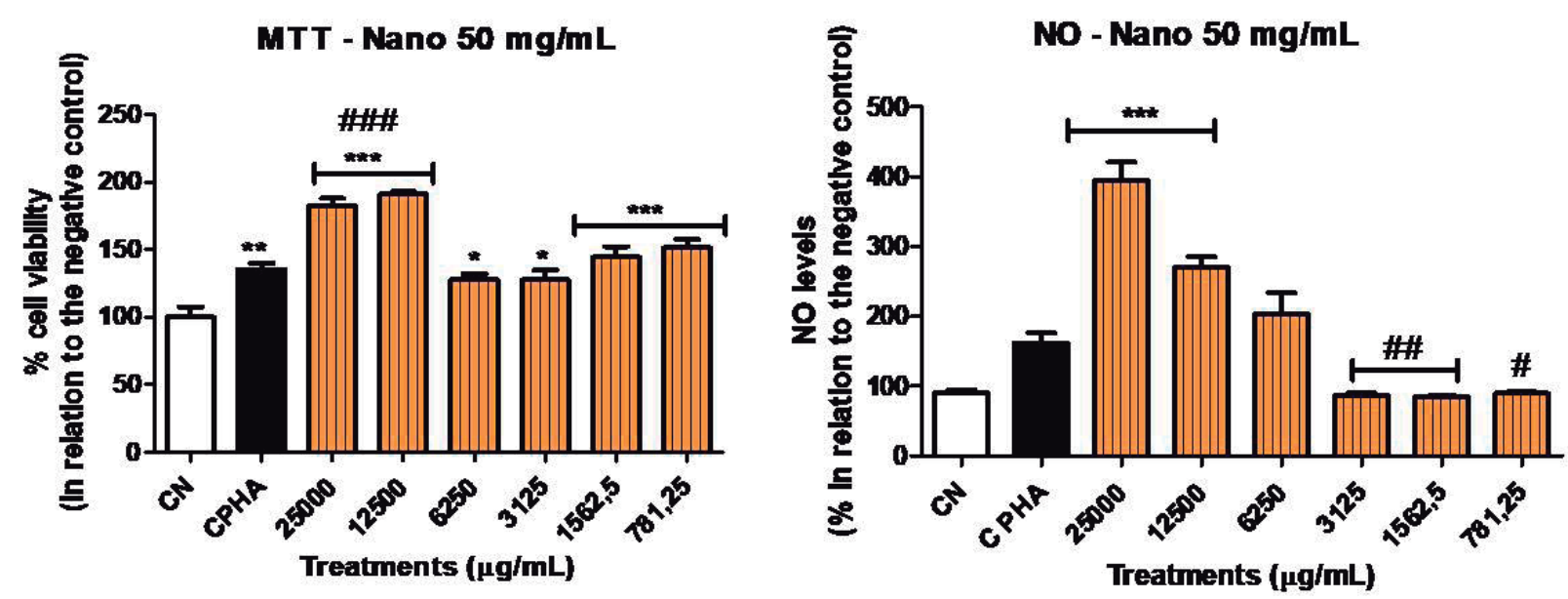

Source: Author's construction.

Bony et al. (2012) evaluated the chemical compositions and anti-inflammatory properties of the unsaponifiable ethanolic fraction of tucumã pulp oil in activated macrophages J774 and in an endotoxic shock model in mice. This decreased the levels of nitric oxide (NO), prostaglandin E2, TNF- $\alpha$ and production of interleukins. The anti-inflammatory properties of the unsaponifiable ethanolic fraction were also confirmed in vivo by modulating the serum concentration of TNF $\alpha$, IL-6 and IL-10. Pretreatment with an unsaponifiable fraction of tucumã oil is a promising means to reduce the production of excessive amounts of pro-inflammatory molecules.

In addition, the anti-inflammatory activities of plant extracts have been attributed mainly to flavonoid substances, which are potent inhibitors of the enzyme nitric oxide synthase type 2, responsible for the synthesis of NO, which indirectly block the pathways of cycloxygenase and / or lipoxygenase and protein kinase C and L-arginine / NO. These pathways have been implicated in a series of molecular events involved in anti-inflammatory activities. In addition, flavonoids are able to inhibit phospholipase A2 and phospholipase C, important enzymes in the cascade of mediators of inflammatory processes (MOTTA et al., 2013). 
The percentage of reduction of the mechanical injury done in vitro was determined from the photographs obtained in intervals of up to $48 \mathrm{~h}$ and then the percentage of cells and not cells recognized in the image. The results showed that the NLC was able to significantly stimulate healing activity. The observed parameters referring to the healing potential of the treatments with the NLC were significantly higher in relation to the control groups, showing the healing potential of the NLC (figure 2).

Figure 2 - Result of the healing activity of the nanostructured lipid carrier in different concentrations. Values with $\mathrm{p}<0.05$ were considered statistically significant.

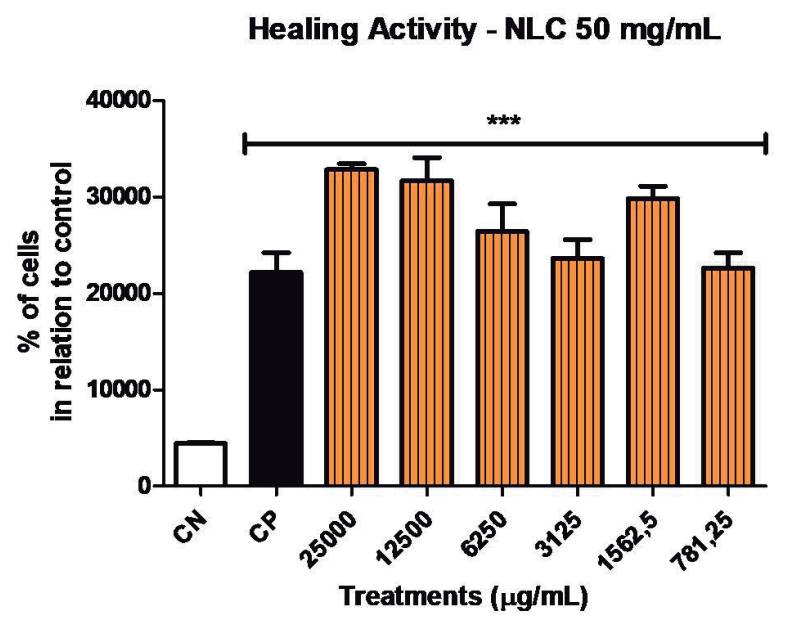

Source: Author's construction.

According to Copetti et al. (2019) the constituents present in tucumã oil and butter have considerable biological effects, such as anti-hyperglycemic activity, cytoprotective effect, lectin, antimicrobial, antioxidant and anti-inflammatory activity. Bioactives derived mainly from secondary metabolites of vegetables such as polyphenols (flavonoids, stilbenes, tannins and phenolic acids), saponins, alkaloids, resins, peptides, polyesterols carotenoids have numerous therapeutic activities (ROSTAGNO; PRADO, 2013), including in the process of healing. The antimicrobial and antioxidant properties of the bioactive substances present in the tucumã fruit are also essential in healing, and may positively favor one or more phases of the tissue repair process (GHOSH; GABA, 2013).

The polyphenols present in tucumã oil have healing effects both in vitro and in vivo, modulating the function of keratinocytes, immune cells, growth factors, angiogenesis and the proliferation of collagen (TSALA et al., 2013), and are also able to improve angiogenesis and decrease the levels of ON and EROs (BAHRAMSOLTANI et al., 2014). In addition, the use of fatty acids, such as omega-3 (also present in tucumã oil and butter) has been studied in the healing and tissue repair process, due to its anti-inflammatory, immune-regulating and anthogenic properties (CASTILHOS et al., 2015).

In a study by Cardoso et al. (2004), the influence of topical administration of $\alpha$-linolenic (n-3), linoleic (n-6) and oleic (n-9) acids on the wound healing process in rats was evaluated. The authors observed that animals treated topically with oleic and linoleic acids showed a significant reduction in the wound area after the fifth day of treatment and inhibition of local nitric oxide production, in the 
first 48 hours after surgery. In addition, a study by Hatanaka et al. (2005) demonstrated that oleic and linoleic acids can be used in wounds as pro-inflammatory agents during the inflammatory phase of the healing process, contributing to accelerate the tissue repair process.

In in vitro tests, Hatanaka and Curi(2007) observed that oleic and linoleic acids act on neutrophils, increasing the release of reactive oxygen species (ROS) and increasing the release of TNF-a, IL-1b, CINC-2 / ae VEGF-a. It is known that ROS are important signalers during the healing process, being involved in signaling for cytokine migration, differentiation and release and that TNF-a, IL-1b and CINC-2 / a are important in inducing the migration of neutrophils and mononuclear cells to the inflamed site and VEGF-a is important in inducing angiogenesis and vascularization of the injured region. In this sense, according to the authors, oleic and linoleic acids have a pro-inflammatory effect inducing the release by neutrophils of the cited cytokines. Regarding the topical use of fatty acids, these are successfully used in the treatment of open lesions, with or without infection, in humans, mainly in Latin American countries. It is believed that fatty acids are accelerators of the healing process, acting as chemotactic agents for leukocytes, promoting angiogenesis, in addition to wound hydration (CURI; HATANAKA, 2007).

In summary, all tested concentrations of the NLC were able to promote cell migration / proliferation in the gaps. This nanostructured system, therefore, proved to be effective in promoting wound healing in vitro. Thus, it is possible to suppose that the fatty acids present in the oil and butter of tucumã have acted in increasing cell proliferation, providing the healing process.

\section{CONCLUSION}

The tucumã nanostructured lipid carrier was successfully developed by the homogenization method using Ultra Turrax, remaining stable for a considerable period of time. In addition, the results of anti-inflammatory activity with Phytohemagglutinin demonstrated that the NLC showed anti-inflammatory activity in concentrations of $3125,1562.5$ and $781.25 \mu \mathrm{g} / \mathrm{mL}$, in addition to being able to increase cell proliferation in HFF- cells. 1, suggesting an adequate profile for tissue repair and healing.

\section{REFERENCES}

ATTAMA, A.A. et al. Lipid Nanoparticulate Drug Delivery Systems: A Revolution in Dosage Form Design and Development. IntechOpen, 2012. doi:10.5772/50486.

BAHRAMSOLTANI, R. et al. Medicinal plants and their natural components as future drugs for the treatment of burn wounds: an integrative review. Archives of dermatological research, v. 306, n. 7, p. $601-617,2014$. 
BONY, E. et al. Chemical Composition and Antiinflammatory Properties of the Unsaponifiable Fraction from Awara (Astrocaryum vulgare M.) Pulp Oil in Activated J774 Macrophages and in a Mice Model of Endotoxic Shock. Plant Foods Human Nutrice, v. 67, p. 384-392, 2012.

CARDOSO, B.R.C. et al. Influence of Topical Administration of n-3 and n-6 Essential and n-9 Nonessential Fatty Acids on the Healing of Cutaneous Wounds. Wound Repair And Regeneration, v. 12, n. 2, p. 235-243, 2004.

CASTILHOS, T.J. et al. Efeito do ácido graxo ômega-3 na cicatrização de anastomose colônica em ratos, Arquivos Brasileiro de Cirurgia Digestiva. v. 28, n. 4, p. 258-261, 2015.

COPETTI, P. M. et al. Tucumã extracts decreases PML/RARA gene expression in NB4/APL cell line, Archives in Biosciences \& Health. v. 1, n. 1, p. 1-22, 2019.

CHEN, C. et al. Analytical techniques for single-lipossome characterization. Analytical Methods, v. 5, n. 9, p. 2150-2157, 2014.

FERREIRA, E. S. et al. Caracterização físico-química do fruto e do Óleo extraído de tucumã (Astrocaryum vulgare mart). Alimentos e nutrição Araraquara, v. 19, n. 4, p. 427-433, 2008.

GHOSH, P. K.; GABA, A. Phyto-Extracts in Wound Healing. Journal of Pharmacy and Pharmaceutical Sciences, v. 16, n. 5, p. 760-820, 2013.

HATANAKA, E.; CURI, R. Ácidos graxos e cicatrização: uma revisão. Revista Brasileira de Farmácia, v. 88, n. 2 , p. 53-58, 2007.

MACEDO, L. J. et al. Phytotherapy effectiveness in the process of healing of patients with diabetes mellitus tissue diagnosis. ReonFacema, v. 3, n. 1, p. 396-400, 2017.

MACZYNSKI, M. et al. Anti-inflammatory properties of na isoxazole derivative - MZO-2. Pharmacological Reports, v. 68, p. 894-902, 2008.

MOTTA, E.V. S. et al. Atividades antioxidante, antinociceptiva e anti-inflamatória das folhas de Mucuna pruriens. Revista Brasileira de Plantas Medicinais, v. 15, n. 2, p. 264-272, 2013. 
ROSTAGNO, M. A.; PRADO, J. M. Natural product extraction: principles and applications. Royal Society of Chemistry, 2013.

SOUZA FILHO, W.P. S.et al. Effects of nanocapsules containing all-trans-retinoic acid under hemolytic and coagulation activity. Archives in Biosciences \& Health, v. 1, n. 1, p. 125-138, 2019.

TSALA, D.E.; DAWE, A.; HABTEMARIAM, S. Natural wound healing and bioactive natural products. Phytopharmacology, v. 4, n. 3, p. 532-560, 2013. 